\title{
Evaluation of chañar seed cake from biodiesel production as a soil amendment
}

\author{
C. Santibáñez ${ }^{1 *}$ and M.T. Varnero ${ }^{2}$ \\ ${ }^{1}$ Universidad Mayor, Facultad de Ciencias Silvoagropecuarias, Santiago, Chile. ${ }^{2}$ Universidad de Chile, Facultad \\ de Ciencias Agronómicas, Santiago, Chile.*Corresponding author: claudia.santibanez@umayor.cl
}

\begin{abstract}
One of the major problems for biodiesel producers is the disposal of the seed cake after expelling oil from seeds. Every ton of biodiesel results in 2.5 to 3 tons of seed cake as byproduct. The physicochemical characteristics of this residue indicate that itcould be converted into valuable organic fertilizer. In order to evaluate the feasibility of using chañar seed cake from biodiesel production as a soil amendment, a greenhouse pot experiment was conducted. Seed cake was applied mixed with soil, at rates of $0,6,12$ and $24 \%$. A single seedling of chañar per pot was transplanted and after six months, plants were harvested for foliar analyses as well as some physiological characteristics. Seed cake application increased dry biomass production and the shoot concentrations of $\mathrm{N}$ and chlorophyll. There were no evident symptoms of phytotoxicity. The application of seed cake at $12 \%$ proved superior to the $6 \%$ treatment and the control; ahigher dose of seed cake (24\%) was not significantly different from the treatment with $12 \%$ in terms of dry biomass production of chañar, foliar contents of N, P, Kor total chlorophyll. However, plant aerial biomass was significantly correlated with soil microbial respiration and soil $\mathrm{C}$ biomass.
\end{abstract}

Keywords: Chañarseed cake, soil amendment, biofertilizer

\section{Introduction}

Biodiesel production from vegetable oils remains a strong growth market in the United States, Canada and the European Union (Anderson et al., 2003). The majority of edible vegetable oils have excellent characteristics that have made them the most commonly used raw materials for biodiesel production, with the objection of their high prices (Kyu-Wan et al., 2007; Eriksson et al., 2009). However, there are critical issues which need to be addressed to make the production of biodiesel a techno-economically viable and ecologically acceptable renewable substitute or additive to diesel. In spite of the favorable impact, biodiesel production presents some drawbacks related to the economics of the process, deeply dependent on feedstock costs (Yuang et al., 2008). The biodiesel production process produces, simultaneously and inevitably, the fuel and other byproducts. The economic viability of the biodiesel industry depends to a large extent on the ability of the industry to derive value from the biofuel it produces as well as the byproducts that are generated during the process. 
Facilities integrating recovery and reuse of their residues are a key characteristic of biorefineries, which have been identified as the most promising route to the creation of a newbio-based industry.In general, 50\% (dry weight basis) of the collected fruits of biodiesel feedstock are seeds (kernels). At most $35 \%$ of these seeds are converted into vegetable oil; the remaining $65 \%$ material is residual oil seed cake. In short, more than $85 \%$ of a cultivated bio-resource (seed outer coats and oil seed cake) is remaining unutilized in biodiesel production (Chandra et al., 2011). After the extraction process, the remaining solid part is called seed cake residue (Erikson et al., 2009; Ozcimen and Karaosmanoglu, 2004). Disposal of the seed cake is one of the major problems being faced by biodiesel producers across the world. A 1 ton per day biodiesel plant produces 2.5 to 3 tons of seed cake. Cake composition is mainly cellulose, hemicelluloses and lignin, depending on the type of seed plant, which also determines its possible applications (Culcuoglu et al., 2002). Nevertheless, the expansion of biodiesel production makes it necessary to find sustainable applications for the byproducts and residues. This may entail economic and environmental improvements for the biodiesel production process.

Oil seed cake obtained from the oil extraction process can be converted into valuable soil organic fertilizer. The nitrogen content in de-oiled cake varies depending on the source and up to $6.48 \%$ has been reported in the literature (GTZ, 1995). If handled properly,this organic residue would maintain the natural balance of essential nutrients and organic matter, and thereby promote better harvests from crops. In addition, seed cake contains some residual oil and consequently contains insecticide properties and can reduce the number of nematodes in the ground (Tiyagi and Alam, 1995; Ramachandran et al., 2007). For example, Sinha et al. (2011) evaluated combinations of Jatropha curcas seed cake with other organic residues in order to obtain an appropriate soil amendment and to increase soil fertility. The results of this study showed a significant increase in J. curcas growth, as well as an increase in extractable micronutrient content and soil enzymatic activity. However, depending on the composition of the seed, some seed cakes have been shown to have a detrimental effect on seed germination, plant growth and microbial activity (Martín et al., 2002; Alguacil et al., 2008). In fact, several studies have reported phytotoxic and antimicrobial effects of several seed cakes due to the content of phytotoxic substances (e.g. phenols, tannins, organic acids, hexane) (Linares et al., 2003; Martín et al., 2002; Vinay and Kanya, 2008). Chile has wide variations in climate and soil conditions, and thus has a wide variety of domestic plants that produce oil. But the lack of information on the composition and utilization of the many and varied oilseeds indigenous to Chile is more of a problem than is a real shortage of oils. The seeds of chañar, Geoffroeadecorticans (Gillies ex Hook. \& Arn) Burkart,satisfy the availability concern of a biodiesel source in a country such as Chile. The plant grows well in the semi-arid areas of Chile, where little in the way of alternative commercial farming has been established (Lewis et al., 1990). Chañaris a nonedible oil source native to semiarid regions of South America. The biodiesel obtained from this oil exhibits high quality properties and has been identified as a prospective source of biodiesel (Santibáñez, 2011; Santibáñez et al., 2012). The main purpose of this study was to evaluate the use of chañar seed cake from biodiesel production as soil amendment.

\section{Materials and Methods}

\subsection{Sample collection}

Soil samples and mature fruits of chañar were collected from Elqui Province, Coquimbo Region, Chile, during May, 2010. To extract oil from seeds an IBG Monforts Oeokotec Komet model CA59G screw press was used and the residual oil was removed by hexane extraction through repeated percolation. The de-oiled seed cake was dried at $45^{\circ} \mathrm{C}$ for $24 \mathrm{~h}$ in an oven and powdered in a hand mill and passed through a 60 mesh sieve. 


\subsection{Physical and chemical analysis of soil and seed cake}

The soils and seed cake of chañar were analyzed for the following parameters prior to the plant growth experiment: $\mathrm{pH}$ (solid:deionized water $=1: 2.5$ $\mathrm{w} / \mathrm{v}$ ) using a $\mathrm{pH}$ meter; electrical conductivity (EC; saturated paste extract) using an EC meter; total organic carbon was determined by the Walkey and Black wet dichromate oxidation method (Nelson and Sommers, 1996) and total nitrogen (N) was determined by the Kjeldahl digestion-distillation method (Bremner, 1996). Moisture retention was measured at field capacity and permanent wilting point (0.3 and 15 bar) (Klute, 1986).

\subsection{Experimental design}

A randomized pot experiment was established in a greenhouse to evaluate growth and some physiological parameters of chañar grown on seed cake-amended soil. Seed cake was applied mixed with the soil at rates of $0,6,12$ and $24 \% \mathrm{v} / \mathrm{v}(\mathrm{C}, \mathrm{T} 6, \mathrm{~T} 12, \mathrm{~T} 24)$ and placed in pots ( $12.5 \mathrm{~cm}$ in diameter and $12 \mathrm{~cm}$ height). The soil used in this study has low organic matter content $(1.3 \%)$. Therefore, rates of seed cake were defined in order to obtain an organic matter content in the mixtures between 2 and $8 \%$. Subsequently, a single seedling of chañar per pot was transplanted. Each treatment was replicated 5 times and a total of four treatments (Table 1) and 20 experimental units were randomly arranged in the greenhouse at $23{ }^{\circ} \mathrm{C}$. Each pot was watered two times per week with 150 $\mathrm{ml}$ of deionized water. After six months, the plants were harvested and separated into roots and shoots for dry biomass determination, nutrient content, and chlorophyll analysis as well as some physiological analyses. Soil pore-water of the mixtures was collected after 0 and 6 months using lysimeters. These samplers were vertically inserted into the soil of each pot to 5 $\mathrm{cm}$ depth. The lysimeter was a $5 \mathrm{~cm}$-length porous material connected to a syringe at the base which extracted the water sample by vacuum and served as a pore-water reservoir. Soil pore-water samples were kept in acid-washed polyethylene plastic vials $(15 \mathrm{ml})$, $\mathrm{pH}$ and electrical conductivity determinations were measuredup to $10 \mathrm{~min}$ after sample collection with a combination $\mathrm{pH}$ and $\mathrm{EC}$ electrodes. Dissolved organic carbon (DOC) was determined using an Apollo 9000 TOC analyzer (Tekmar-Dohrmann, USA) following U.S. EPA method 415.1 (USEPA, 1983).

\subsection{Plant tissue analysis}

At the end of the experiment, foliar chlorophyll content in fresh leaves was determined from $80 \%$ acetone extracts by spectrophotometry at 646 and $664 \mathrm{~nm}$ (Harbone, 1984). Subsequently, the plants were harvested and separated into roots and shoots. All plant tissues were thoroughly washed with ultrapure water $(<18 \mathrm{M} \Omega / \mathrm{cm})$ and then dried in a forced air oven at $45^{\circ} \mathrm{C}$ for $72 \mathrm{~h}$. The dried plant tissues were weighed to determine root and shoot dry biomass. The plant tissues were ground to a powder in an agate ball mill. Shoot nitrogen content was determined by the micro Kjeldahl method with a Kjeltec Auto 1030 Analyzer after digesting the samples in concentrated $\mathrm{H}_{2} \mathrm{SO}_{4}$ with a selenium catalyst. Shoot phosphorus content was determined with the stannous chloride method using a spectrophotometer (Allen et al., 1986).

\subsection{Microbial analysis}

Substrate aliquots for microbial analysis were kept in hermetically sealed plastic bags and stored at $4^{\circ} \mathrm{C}$ in the dark until their microbiological analysis. Basal respiration was determined by placing $50 \mathrm{~g}$ of each substrate sample at $70 \%$ of field capacity in a $0.5 \mathrm{~L}$ air-tight sealed jar along with $10 \mathrm{~mL}$ of $1 \mathrm{~N} \mathrm{NaOH}$, followed by incubation for 28 days in the dark at $28^{\circ} \mathrm{C}$. The $\mathrm{C}-\mathrm{CO}_{2}$ evolution was periodically determined by titration (Anderson, 1982). Basal respiration rate was calculated based on cumulative $\mathrm{CO}_{2}$ evolution over the 28 days period. Microbial biomass $\mathrm{C}$ (MBC) was determined by the chloroform fumigation extraction method (Gregorich et al., 1990). This parameter is estimated by the difference between fumigated and non-fumigated samples. Anextraction efficiency 
(Kec factor) of 0.45 is often used to calculate he MBC value (Sparling et al., 1990). The microbial metabolic quotient was calculated as basal respiration $\left(\mu \mathrm{g} C-\mathrm{CO}_{2} \mathrm{~h}^{-1}\right.$ ) per $\mathrm{mg}$ of $\mathrm{MBC}$ according to Anderson and Domsch (1990).

\subsection{Statistical analysis}

Significant differences between the treatments and the control were determined using a one-way ANOVA and a post hoc Tukey test. Significance was reported at $p<0.05$. Normality was checked with the Shapiro-Wilks test and a Levene statistic test was performed to check the homogeneity of variances. The software INFOSTAT 1.1 (Universidad Nacional de Córdova, Argentina, 2002) was used for all

\section{Results and Discussion}

\subsection{Chemical and physical characteristics of soil and seed cake}

The main chemical and physical characteristics of the experimental soil and seed cake are listed in Table 1. According to The United States Salinity Laboratory (Rhoades and Clark, 1978) the studied soil may be classified as slightly saline, while the seed cake was non-saline. With regard to $\mathrm{pH}$, the soil was classified as slightly alkaline and the seed cake as neutral. According to Etchevers (1980) the soil has extremely low content of both organic carbon and nitrogen and poor moisture retention capacity. However, seed cake shows complementary properties, such as high moisture retention capacity and high nutrient contents, which could help to improve soil characteristics.

Table 1. General chemical and physical properties of soil and seed cake (dry weight basis)

\begin{tabular}{lll}
\hline Property & Soil & Seed cake \\
\hline pH in 1:2.5 (soil/water ratio) & 8.03 & 6.87 \\
Electrical conductivity, EC $\left(\mathrm{dS} \mathrm{m} \mathrm{m}^{-1}\right)$ & 3.04 & 2.08 \\
Organic carbon $(\%)$ & 0.76 & 15.4 \\
Total nitrogen $\left(\mathrm{mg} \mathrm{kg}^{-1}\right)$ & 586 & 5425 \\
Total phosphorus $\left(\mathrm{mg} \mathrm{kg}^{-1}\right)$ & 2375 & 2823 \\
Total potassium $\left(\mathrm{mg} \mathrm{kg}^{-1}\right)$ & 123 & 451 \\
Available nitrogen $\left(\mathrm{mg} \mathrm{kg}^{-1}\right)$ & 19 & 39 \\
Available phosphorus $\left(\mathrm{mg} \mathrm{kg}^{-1}\right)$ & 8 & 34 \\
Available potassium $\left(\mathrm{mg} \mathrm{kg}^{-1}\right)$ & 75 & 414 \\
Moisture retention at 0.3 bar $(\%)$ & 10.9 & 53.2 \\
\hline
\end{tabular}

\subsection{Pore water properties}

The results showed that the application of seed cake significantly increased the concentrations of dissolved organic carbon (DOC) in the pore water compared to the control (Table 2). The DOC concentrations in porewater increased as the rate of seed cake application increased. The dissolved organic carbon is composed of organic compounds of low molecular weight that are produced during decomposition of organic matter
(Neff and Asner, 2001). ). Fresh organic residues such as the seed cake used in this study are rich in watersoluble organic compounds that were not stabilized by a process such as composting or anaerobic digestion. Therefore it is likely that microorganisms were actively degrading the organic matter and producing high amounts of DOC.

The application of seed cake tended to decrease the $\mathrm{pH}$ values of mixtures (Table 2). 
Table 2. $\mathrm{pH}$ and dissolved organic carbon in pore-water from seed cake-treated soils at 0 and 6 months

\begin{tabular}{|c|c|c|c|c|}
\hline \multirow[t]{3}{*}{ Treatment } & \multicolumn{2}{|c|}{$\mathrm{pH}$} & \multicolumn{2}{|c|}{ DOC } \\
\hline & \multirow[t]{2}{*}{0 months } & \multirow[t]{2}{*}{6 months } & 0 months & 6 months \\
\hline & & & \multicolumn{2}{|c|}{$-\cdots-m g ~ L^{-1}$} \\
\hline $\mathrm{C}$ & $7.93 \mathrm{a}$ & $7.51 \mathrm{a}$ & $23 \mathrm{a}$ & $19 \mathrm{a}$ \\
\hline T6 & $7.46 \mathrm{a}$ & $7.22 \mathrm{a}$ & $116 \mathrm{~b}$ & $102 \mathrm{~b}$ \\
\hline $\mathrm{T} 12$ & $6.41 \mathrm{~b}$ & $7.19 \mathrm{a}$ & $221 \mathrm{c}$ & $354 \mathrm{c}$ \\
\hline $\mathrm{T} 24$ & $5.92 \mathrm{~b}$ & $7.56 \mathrm{a}$ & $233 \mathrm{c}$ & $257 \mathrm{c}$ \\
\hline
\end{tabular}

Different letters indicate significant differences at $p<0.05$ according to a one way ANOVA and Tukey test.

After three months of seed cake application, the $\mathrm{pH}$ values of pore-water decreased as the rate of seed cake application increased, whereas after 6 months, the effect of the application rate was not significant. Several factors can modify the $\mathrm{pH}$ of the final substrate generated, such as microbial breakdown of organic matter and the process of nitrification of the seed cake.

\subsection{Nitrogen, phosphorus and chlorophyll content in chañar shoots}

The treatments with application of seed cake showed greater shoot contents of $\mathrm{N}, \mathrm{P}$ and chlorophyll than the control $(p<0.05$; Table 3$)$. The shoot $\mathrm{N}$ content in the treatments with seed cake application was within the normal range for plants (3-4\%), and the control showed shoot $\mathrm{N}$ deficiency (Table 3 ). In addition, the plants grown in the control showed poor growth, and extremely thin and yellowish leaves. By contrast, the plants treated with seed cake showed large and vigorous leaves with an intense green color and healthy aspect. The shoot content of $\mathrm{N}$ increased as the rate of seed cake application increased. The application of seed cake increased the content of total chlorophyll (chlorophyll a + chlorophyll b) in the leaves by 87,316 , and $352 \%$ as the dose of seed cake increased (Table 3).

Seed cake allowed greater biomass production in plants, because the $\mathrm{N}$ added with seed cake is an essential element for making proteins and chlorophyll
(Chiu et al., 2006). The N-deficient plants growing on soil exhibit pale green or yellowish leaves, which occurs because the deficiency of $\mathrm{N}$ limits the chlorophyll production in the leaves of the plants (Garnier et al., 1999; Blackmer, 1997).

The chlorophyll contents of plants from this experiment were consistent with the coloration observed and the $\mathrm{N}$ content in the leaves. The leaves of the control (C) showed a green-yellowish coloration due to the low $\mathrm{N}$ contents in the leaves (Table 3), and therefore the control showed a lower content of chlorophyll than the treatments amended with seed cake, which had appropriate levels of foliar N.

\subsection{Dry biomass production}

At harvest, plants grown in the seed cake-treated pots were healthy with no macroscopic symptoms of toxicity. In the control, plants experienced retarded growth and reduced dry shoot biomass production compared to those grown in the treatments amended with seed cake. The dry biomass production is shown in Figure 1. The rate of seed cake application had a significant effect on dry shoot biomass production. Treatments $\mathrm{T} 12$ and $\mathrm{T} 24$ showed higher production of shoot biomass, with no significant difference between them. The differences among treatments in the production of dry root biomass, although suggestive, were not significant. 
Table 3. Foliar contents of macronutrients and total chlorophyll in chañar grown in seed cake-treated soils

\begin{tabular}{lllcc}
\hline Treatment & $\mathrm{N}$ & $\mathrm{P}$ & $\mathrm{K}$ & $\begin{array}{c}\text { Total } \\
\text { chlorophyll }\end{array}$ \\
\cline { 2 - 5 } & & & & $\begin{array}{c}\mathrm{mg} \mathrm{g}^{-1} \text { fresh } \\
\text { weight }\end{array}$ \\
\hline $\mathrm{C}$ & $1.28 \mathrm{a}$ & $0.14 \mathrm{a}$ & $1.38 \mathrm{a}$ & $0.55 \mathrm{a}$ \\
$\mathrm{T} 6$ & $2.79 \mathrm{~b}$ & $0.45 \mathrm{~b}$ & $2.85 \mathrm{~b}$ & $1.03 \mathrm{~b}$ \\
T12 & $3.84 \mathrm{c}$ & $0.51 \mathrm{~b}$ & $2.94 \mathrm{~b}$ & $2.29 \mathrm{c}$ \\
T24 & $5.03 \mathrm{~d}$ & $0.76 \mathrm{c}$ & $2.82 \mathrm{~b}$ & $2.49 \mathrm{c}$ \\
\hline
\end{tabular}

Different letters indicate significant differences at $\mathrm{p}<0.05$ according to a one way ANOVA and Tukey test.

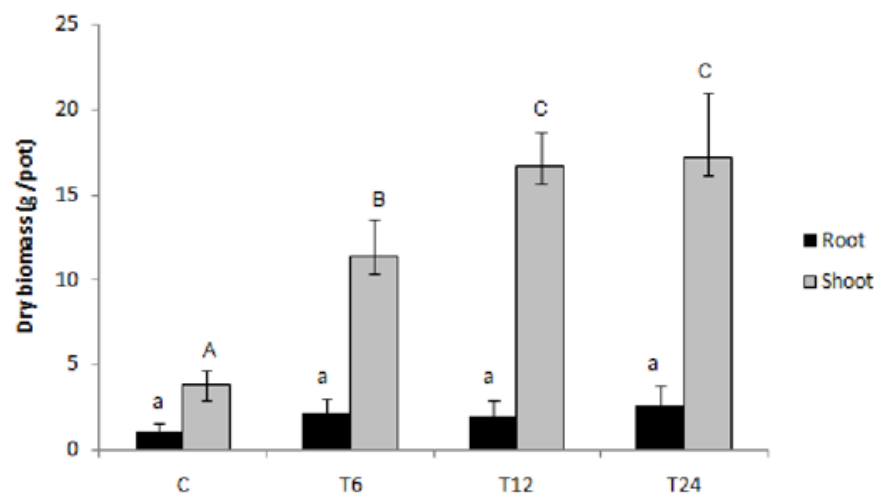

Figure 1. Plant aerial biomass (dry weight basis, d.w.) in experimental treatments (bars indicate standard deviation, $n=5$ ) after 6 months. Different letters indicate significant differences at $p<0.05$ according to a one way ANOVA and Tukey test.

\subsection{Nitrogen, phosphorus and chlorophyll content in chañar shoots}

At the end of the assay accumulated respiration significantly increased in all treatments with addition of seed cake with respect to the control (Table 4). This parameter increased as the dose of seed cake increased. Microbial biomass $\mathrm{C}$ increased in all treatments with addition of seed cake with respect to the control (Table 4) and ranged between $195-419 \mu \mathrm{C} \mathrm{g} \mathrm{g}^{-1}$ allMBC values were significantly greater than the control. Soil $\mathrm{MBC}$ has been used to compare natural and disturbed ecosystems. MBC was lowest in those treatments where $\mathrm{C}-\mathrm{CO}_{2}$ emission was also low. The general increase of both microbial respiration and $\mathrm{MBC}$ in all treatments amended with seed cake can be attributed to the incorporation of easily degradable materials, which stimulate the autochthonous microbial activity of the soil, and to the incorporation of exogenous microorganisms (Perucci, 1992).

A high respiration rate may indicate either an ecological disorder or a high level of productivity in the ecosystem (Islan and Weil, 2000). 
Table 4. Soil microbiological parameters at the end of the experiment

\begin{tabular}{cccc}
\hline Treatment & $\begin{array}{c}\text { Accumulated } \\
\text { respiration } \\
\left(\mathrm{mg} \mathrm{C}-\mathrm{CO}_{2} / 100 \mathrm{~g}\right)\end{array}$ & $\begin{array}{c}\text { Microbial } \\
\text { biomass C } \\
\left(\mu \mathrm{g} \mathrm{g}^{-1}\right)\end{array}$ & $\begin{array}{c}\text { Metabolic } \\
\text { quotient } \\
\left(\mu \mathrm{gC}-\mathrm{CO}_{2} \mathrm{mg} \mathrm{Cbio}^{-1} \mathrm{~h}^{-1}\right)\end{array}$ \\
\hline $\mathrm{C}$ & $80 \pm 11 \mathrm{a}$ & $56 \pm 8 \mathrm{a}$ & $3.0 \pm 0.65 \mathrm{a}$ \\
$\mathrm{T} 6$ & $205 \pm 32 \mathrm{~b}$ & $195 \pm 22 \mathrm{~b}$ & $0.8 \pm 0.41 \mathrm{~b}$ \\
$\mathrm{~T} 12$ & $319 \pm 43 \mathrm{c}$ & $386 \pm 47 \mathrm{c}$ & $0.9 \pm 0.49 \mathrm{~b}$ \\
$\mathrm{~T} 24$ & $526 \pm 78 \mathrm{~d}$ & $419 \pm 58 \mathrm{c}$ & $1.2 \pm 0.52 \mathrm{~b}$ \\
\hline
\end{tabular}

Cbio: Microbial biomass C. Different letters indicate significant differences at $p<0.05$ according to a oneway ANOVA and Tukey test.

Table 5.Pearson's correlation coefficient between plant aerial biomass and several microbial and chemical properties of experimental substrates $(n=20)$.

\begin{tabular}{ll}
\hline Variable & $\mathrm{r}$ \\
\hline SOC & 0.56 \\
DOC & 0.32 \\
pH & 0.18 \\
Microbial respiration & $0.59^{*}$ \\
Metabolic quotient & 0.26 \\
Microbial biomass C & $0.71^{*}$ \\
\hline
\end{tabular}

DOC, dissolved organic carbon; SOC, soil organic carbon *Correlation is significant at the 0.01 level (two tailed)

The respiration rate per unit of microbial biomass or metabolic quotient $\left(\mathrm{qCO}_{2}\right)$ is a variable of easier interpretation. The $\mathrm{qCO}_{2}$ has been utilized as a microbial stress indicator and interpreted as "microbial efficiency", since it is a measurement of the energy necessary to maintain metabolic activity in relation to the energy necessary for synthesizing biomass (Bardgett and Saggar, 1994). This parameter is useful to evaluate the stability and degree of maturity of a restored system, and should be high in young (immature) soils and low in mature soils. However, soils under stress would also present higher $\mathrm{qCO}_{2}$ values than non-stressed soils. The values of $\mathrm{qCO}_{2}$ in all treatments were within the range of reported values in the literature $\left(0.5-3 \mu \mathrm{g}-\mathrm{C}_{2} \mathrm{CO}_{2}\right.$ mg $\left.\mathrm{Cbio}^{-1}\right)$ (Beck and Bengel, 1992; Kandeler et al., 1993). However, they decreased in all treatments with addition of seed cake and the highest value was recorded in the control (Table 4). This might reflect low soil quality and low efficiency of functioning organisms, because the soil evaluated showed limiting edaphic conditions.

\subsection{Correlation between plant aerial biomass and some microbial and chemical parameters}

Correlation analysis revealed significant positivecorrelation of plant aerial biomass with microbial respiration and MBC (Table 5). 


\section{Conclusions}

Overall it is seen that application of appropriate amounts of organic formulations based on de-oiled chañar cake as soil amendment will lead to significant improvement in plant growth parameters. The results suggest that application of seed cake at $12 \%$ proved superior to $6 \%$ treatment and the control, and showed no significant difference with the treatment with higher dose of seed cake (24\%) in terms of chañar dry biomass production, foliar content of N, P, K or total chlorophyll. Plant aerial biomass was significantly correlated with soil microbial respiration soil microbial biomass $\mathrm{C}$.

In addition,use ofseed cake would also provide an opportunity for energy savings and reduction of $\mathrm{CO}_{2}$ emissions which will ultimately mitigate global warming. This gainful utilization also provides a solution for the problem associated with the safe disposal of de-oiled cake waste. However, these results should be tested under field conditions in order to confirm their efficacy under semi-arid Mediterranean climate conditions.

\section{Acknowledgements}

The authors thank the National Commission for Scientific and Technological Research (CONICYTChile) for their financial support (FONDECYT Project No. 11085043).

\section{References}

Allen, S.E., Grimshaw, H.M., Parkinson, J.A., Quarmby, C., Roberts, J.D. 1986. Chemical analysis. In: Chapman S.B. (ed), Methods in plant ecology, Blackwell Sci. Publ., Oxford. pp 411-466,

Alguacil, M.M., Caravaca, F., Azcón, R., Roldán, A. 2008. Changes in biological activity of a degraded
Mediterranean soil after using microbially-treated dry olive cake as a biosolid amendment and arbuscular mycorrhizal fungi. Eur. J. Soil Biol. 44, 347-354.

Anderson, J.P.E. 1982. Soil respiration, In: Methods of Soil Analysis, Part 2. Chemical and Microbiological Properties, A.L. Page, Ed., Soil Sci Soc Am. Madison, Wisconsin, USA. pp. 837-871.

Anderson, TH., Domsch, K.H. 1990. Application of ecophysiological quotients $\left(\mathrm{qCO}_{2}\right.$ and $\left.\mathrm{qD}\right)$ on microbial biomasses from soils of different cropping histories, Soil Biol.Biochem. 22, 251-255.

Anderson, D., Masterson, D., McDonald, B., Sullivan, L. 2003. Industrial Biodiesel Plant Design and Engineering: Practical Experience. Crown Iron WorksCompany. Minneapolis, Minnesota 55440, USA. Hotel, Putrajaya, Malaysa.

Bardgett, G.D., Saggar, S. 1994. Effect of heavy metal contamination on the short-term decomposition of labelled (14C) in a pasture soil. Soil Biol. Biochem. 26, 727-733.

Blackmer, A.M. 1997. Soil fertility: visually rating nitrogen sufficiency. Integrated Crop Management Newsletter, IC-478-R12. Iowa: Iowa State University; p. 2.

Beck, T., Bengel, A. 1992. Die mikrobielle Biomasse in Böden. Teil I-ihre Bestimmung, Indikator funktion und Bedeutungfür die Stoffumsetzungen, In: Schule u Beratung. Pp. 6-10.

Bremner, JM. 1982. Nitrogen-total. In: Sparks, DL, Page, A.L., Helmke, P.A., Loeppert, R.H., Soltanpour, P.N., Tabatabai, M.A., Johnson, C.T., Sumner, M.E.(eds.). Methods of soil analysis.

Chandra, R., Vijay, V.K., Subbarao, P.M.V. 2011. Production of methane from anaerobic digestion of Jatropha and Pongamia oil cakes. Appl. Energy doi:10.1016/j.apenergy.2010.10.049 
Chiu, K.K., Ye, Z.H., Wong, M.H. 2006. Growth of Vetiveriazizanioides and Phragmitiesaustralis on $\mathrm{Pb} / \mathrm{Zn}$ and $\mathrm{Cu}$ mine tailings amended with manure compost and sewage sludge: a greenhouse study. Bioresour. Technol. 97, 158-70.

Culcuoglu, E., Unay, E., Karaosmanoglu, F. 2002. Rapeseed Cake as a Biomass Source. Energy Sources. 24, 329-336.

Etchevers, J. 1980. Manual de referencia para métodos rutinarios de análisis de suelo. Escuela de Agronomía, Depto. de Suelos. Boletín Técnico $N^{\circ}$ 65, Chillán: Universidad de Concepción. p 30.

Garnier, E, Salager, J.L., Laurent, G., Sonie, L. 1999. Relationships between photosynthesis, nitrogen and leaf structure in 14 grass species and their dependence on the basis of expression. New Phytol. 143,119-29.

Gregorich, E.G., Wen, G., Voroney, R.P., Kachanoski, R.G. 1990. Calibration of a rapid direct chloroform extraction method for measuring soil microbial biomass C. Soil Biol.Biochem. 22, 1009-1011.

GTZ. 1995. Jatropha oil as fuel. GTZ Jatropha Energy Project, October 1995.

Harbone, J.B. 1984. Phytochemical Methods: A Guide to Modern Techniques of Plant Analysis. London: Chapman and Hall. p. 216.

Islan, K.R., Weil, R.R. 2000. Soil quality indicator proprieties in mid-Atlantic soils as influenced by conservation management. J. Soil Water Conserv. 55, 69-78.

Kandeler, E, Margesin, R., Öhlinger, R., Schinner, F. 1993. Bodenmikrobiologisches MonitoringVorschläge für eine Bodenzustandsinventur. Die Bodenkultur. 44,357-377.

Klute, A. 1986. Water retention: laboratory methods. In: Klute, A, editor. Methods of Soil Analysis: Part 1 - Physical and Mineralogical Methods. Madison,
Wisconsin: American Society of Agronomy/ Soil Science Society of America. p. 635-62.

Lee, K.W., Yu, J.X., Mei, J.H., Yan, L., Kim, Y.W., Chung, K.W. 2007. A kinetic study on the transesterification of glycerylmonooleate and soybean used frying oil to biodiesel. J. Ind. Eng. Chem. 13, 799-807.

Lewis, J.P., Stofella, S.L., Prado, D.E., Pire, E.F., Franceschi, E.A., Carnevale, N.J. 1990. Dynamics and development of floristic richness in the vegetation of a large depressed area of the Great Chaco. Flora. 184,63-77.

Linares, A., Caba, J.M., Ligero, F., de la Rubia, T., Martínez, J. 2003. Detoxification of semisolid olive-mill wastes and pine-chip mixtures using Phanerochaeteflavido-alba,Chemosphere.51, 887891.

Martín, J., Sampedro, I., García-Romera, I., García-Garrido, J.M., Ocampo, J.A. 2002. Arbuscularmycorrhizal colonization and growth of soybean (Glycine max) and lettuce (Lactuca sativa) and phytotoxic effects of olive mill residues, Soil Biol. Biochem. 34, 1769-1775.

Neff, J., Asner, G.P. 2001. Dissolved organic carbon in terrestrial ecosystems: synthesis and a model. Ecosystems. 4, 29-48.

Nelson, D.W., Sommers, L.E. 1996. Total carbon, organic carbon and organic matter. In: Sparks DL, Page AL, Helmke PA, Loeppert RH, Soltanpour PN, Tabatabai MA, Johnson CT, Sumner ME, editors. Methods of Soil Analysis. Part 3 Chemical Methods. Soil Science Society of America Book SeriesMadison, WI.: SSSA; p. 961-1010.

Ozcimen, D., Karaosmanoglu, F. 2004.Production and Characterization of the Bio-oil and Biochar from Rapeseed Cake, Renew. Energy. 29,779-787. 
Perucci, P. 1992. Enzyme activity and microbial biomass in a field soil amended with municipal refuse. Biol.Fertil. Soils. 14,54-60.

Ramachandran, S., Singh, S.K., Larroche, C., Soccol, C.R., Pandey A. 2007. Oil cakes and their biotechnological applications - A review. Biores. Technol. 98, 2000-2009.

Rhoades, J.D., Clark M. 1978. Sampling Procedures and Chemical Methods in use at the United States Salinity Laboratory for Characterizing SaltAffected Soils and Waters. Riverside, California: US Salinity Laboratory. Memo Report. p. 112.

Santibáñez, C. 2011. Chañar (Geoffroeadecorticans) oil as a prospective source of biodiesel in semiarid regions. CurrOpinBiotechnol. doi:10.1016/j. copbio.

Santibáñez, C., Varnero, M.T., Homer, I. 2012. Characteristics of Geoffroeadecortican soil seed from Chile and its potential as biodiesel feedstock. Proceedings of the Fourth International Symposium on Energy from Biomass and Waste, Venice, Italy. PF08-Biofuel.

Sinha, A., Srivastava, P., Singh, N., Sharma, P.N., Behl H.M. 2011. Optimizing organic and mineral amendments to jatropha seed as organic fertilizer. Arch. Agron. Soil Sci. 57, 193-122.
Sparling, G.P., Feltham, C.W., Reynolds, J., West, A.W., Singleton, P. 1990. Estimation of soil microbial $\mathrm{C}$ by a fumigation extraction method: use on soils of high organic matter content, and a reassessment of the KEC-factor. Soil Biol. Biochem. 22, 301-307.

Tiquia, S.M. 2000. Evaluating phytotoxicity of pig manure from the pig - on - litter system. En: P.R. Warman, B.R. Taylor (eds.). Proceedings of the International Composting Symposium, CBA Press Inc. Truro, NS, Pp. 625-647.

Tiyagi, S.A., Alam, M.M. 1995. Efficacy of oil-seed cakes against plant-parasitic nematodes and soilinhabiting fungi on mungbean and chickpea. Biores. Technol. 51, 233 -239.

U.S. Environmental Protection Agency. 1983. Methods for chemical analysis of water and wastes, EPA, Washington DC.

Vinay, B.J., Kanya, T.C.S. 2008. Effect of detoxification on the functional and nutritional quality of proteins of karanja seed meal. Food Chemistry. 106, 77-84.

Yuan, X., Liu, J., Zeng, G., Shi, J., Tong, J., Huang, G. 2008. Optimization of conversion of waste rapeseed oil with FFA to biodiesel using response surface methodology. Renew. Energy. 33, 1678-1684. 